\title{
Donald Bán and the Bócan
}

\section{W. A. Craigie M. A.}

To cite this article: W. A. Craigie M. A. (1895) Donald Bán and the Bócan, Folklore, 6:4, 353-358, DOI: $10.1080 / 0015587 X .1895 .9720325$

To link to this article: http://dx.doi.org/10.1080/0015587X.1895.9720325

$$
\text { 曲 Published online: } 14 \text { Feb } 2012 .
$$

Submit your article to this journal

Q View related articles $₫$ 


\section{DONALD BÃN AND THE BÓCAN.}

BY W A. CRAIGIE, M.A.

\section{(Read at Meeting of Fune $19 t h, 1895$.}

THE following interesting Lochaber story is an abstract of two printed Gaelic versions, the first of which appeared in the Gael, vol. vi. p. 142 (1877), to which it was communicated by D. C. Macpherson, and the second in the Glenbard Collection of Gaelic Poetry, by the Rev. A. Maclean Sinclair, p. 297 ff. (189o). The latter was got from an old Lochaber tailor, whose grandfather had personal experience of the supernatural being which figures in it.

Rather more than a century ago there died in Lochaber a man named Donald Bán, son of Angus (Domhnall Bán mac Aonghais), but better known as Donald Bán of the Goblin (Domhnall Bán a' Bhócain), from his experiences with a Bócan, ${ }^{1}$ or goblin, which were well known to all the district. Donald was the last of the the hunters of Macmhic-Raonuill, and belonged to the house of Keppoch, being according to some the son of Angus Odhar, son of Gilleasbuig of Keppoch. He lived at Mounessie and Inverlaire in Glenspean, and his wife was of the MacGregors of Rannoch.

"It was on the hill that Donald first met with the Bocan," but who the Bócan was no one ever knew, and Donald never told it, if he knew it himself. Of course there were good guesses at it. Some believed it to be a "gille" of Donald's, who was killed at Culloden. Donald himself was present at that battle, and in making his escape was wounded in the leg,

- Sometimes written Bochdan; in either case the pronunciation is Böchkan, and the hero's name is pronounced Döll bpän a' vōchkin. The name of the spirit apparently corresponds to the Manx buggane. 
and so captured, but released after trial. One incident of his prison-time is mentioned which contains a curious touch: "While he was in prison he had a dream; he saw himself, Alastair Mac Cholla, and Domhnall Mac Raonuill Mhóir drinking together. This Donald was the man of whom it was said that he had two hearts. He was taken prisoner at Falkirk, and executed at Carlisle." The reason for identifying the "gille" with the Bócan was that on one occasion he had given to a "thigger" (fear faighel) more than pleased his master, and in the quarrel that followed, the gille said, "I will be avenged for this, alive or dead."

Whatever he was, or whatever may have been his reasons the Bócan nearly ruined Donald by the mischief he did him. He destroyed all the food and injured the members of the household. The butter in particular was always dirtied by him. One time Ronald of Aberardair undertook to bring the butter clean to table, by holding his bonnet over it, and carrying his dirk in his hand, but it was dirtied all the same. At night they could get no sleep for stones and clods that came flying about; "the Bócan was throwing things out of the walls, and they would hear them rattling at the head of Donald's bed." 2 Mr. John Mór MacDougall, the clergyman, slept a night or two in the house, but the Bócan would not come while he was there. The tailor's grandfather, Angus mac Alister Bán, had a different experience. "Something seized his two big toes, and he could not get free any more than if he had been caught by the smith's tongs. He could not get moved. It was the Bócan, but he did nothing more to him." High and low were witnesses to the pranks which this spirit carried dn, but not even Donald himself ever saw him in any shape whatever.

1 This, like the Lowland thigger, Norse Tigger, denotes a poor man who asks assistance from his richer neighbour in the way of seed-corn, \&c.

- For similar stone-throwing compare "Strange Pranks plaid by the Devil at Woodstock," and the "Devil of Glenluce, \&c.," being Relations VI. and XI. in Sinclair's Satan's Invisible World Discovered. 
So much did Donald suffer from his attacks that he finally decided to remove to another house, in hopes that the visitations would cease. He took everything with him except a harrow (cliath chliata), which he left at the side of the house, but before they had got far on the road the harrow was seen coming after them. "Stop, stop," said Donald, "if the harrow is coming after us we may as well go back again." So he returned, and made no further attempt to escape from the visitations. What the harrow had to do with it is left unexplained.

The Bócan had a particular spite against Donald's wife, the "Nic Ghriogair." The night he parted with Donald he went on the roof of the house, and cried, "Are you asleep, Donald Bán?" "Not just now," said Donald. "Put out that long grey tether, the MacGregor wife," said he. "I don't think I'll do it to-night," said Donald. "Come out yourself then, and leave your bonnet." The goodwife thought that he was outside, and whispered in Donald's ear as he was rising, "Won't you ask at him when the Prince will come?" Hardly were the words out of her mouth when the Bócan answered her, "Didn't you get enough of him before, you grey tether?"

The Rev. Mr. Sinclair's version gives a still more curious account of what took place at the Bocan's last visit. "The last night that the Bócan came he was saying that such and such other spirits were along with him. Donald's wife said to her husband, 'I should think that if they were along with him they would speak to us.' The Bócan answered, 'They are no more able to speak than the sole of your foot.' 'Come out here, Donald Bán,' said the Bócan. 'I will,' said Donald, 'and thanks be to the good Being that you have asked me.' Donald was going out, and taking his dirk along with him. 'Leave your dirk inside, Donald,' said the Bócan, 'and your knife (sgian) as well.' Donald went out, and he and the Bocan went through Acha-nan-Comhachan by night, and on through rivers and a birch-wood for about three miles 
till they reached the stream of the Fert. When they got to this the Bócan showed him a hole where he had hid ploughirons while he was alive. While Donald was taking the plough-irons out of the hole the two eyes ${ }^{1}$ of the Bócan were putting more fear on him than anything else he ever heard or saw. When he had got the irons, they went home to Mounessie, himself and the Bócan, and parted that night at the house of Donald Bán."

Donald had more connections with the supernatural world than this. A cousin of his mother was said to have been carried away by the fairies, and one night Donald saw him among them, dancing as hard as he could. He was also out hunting in the year of the great snow, and at nightfall saw a man on the back of a deer ascending a great rock. He heard the man saying, "Home, Donald Bán," and wisely took the advice, for that night there fell eleven feet of snow in the very place where he had intended to stay.

While Donald was troubled with his strange visitant, he composed a hymn which has been preserved by tradition. Though it gives but little information on the main point, it goes to prove the fact of the hauntings so far as proof can be asked for, and the following literal translation will show how Donald himself regarded the affair.

\author{
The Iyma of Donald Bán of the Bócan. \\ O God that createdst me so helpless, \\ Strengthen my belief and make it firm. \\ Command an angel to come from Paradise \\ And take up his abode in my dwelling, \\ To protect me from every trouble \\ That wicked folks are putting in my way; \\ Jesus that didst suffer thy crucifixion, \\ Restrain their doings, and be with me thyself.
}

' Compare the "True Narrative of the Drummer of Tedworth," in Satan's Invisible World Discovered, p. 71. "The exact shape and proportion he could not discover, but he saith he saw a great body with two red glowring or glaring eyes, which for some time were fixed steadily upon him, and at length disappear'd." 
Little wonder though I am thoughtful$\Lambda$ lways at the time when I go to bed The stones and the clods will ariseIIow could a saint get sleep there ! I am without peace or rest, Without repose or sleep till the morning; $O$ thou that art in the throne of grace, Behold my treatment and be a guard to me.

Little wonder though I am troubled, So many stories about me in every place, Some that are unjust will be saying "It is all owing to himself, that affair." Judge not except as you know, Though the Son of God were awaking you ; No one knows if I have deserved more Than a rich man that is without care.

Although I am in trouble at this time, Verily, I shall be doubly repaid, When the call comes to me from my Saviour I shall receive mercy and new grace; I fear no more vexation When $I$ ascend to be with thy saints; $O$ thou that sittest on the throne Assist my speaking and accept my prayer.

O God, make me mindful

Night and day to be praying, Seeking pardon richly For what $I$ have done, on my knees. Stir with the Spirit of Truth True repentance in my bosom, That when thou dost send death to seek me, Christ may take care of me.

Donald's troubles, although connected with a genuine Celtic goblin and presenting one or two peculiar features, are evidently of much the same class as those described in the narratives already mentioned in the foot-notes, and which have been heard of even down to our own day. Had there been any one at the time to write down all that was heard and seen, the story might have been much fuller, but 
all the characteristic details of such occurrences are there. The apparent want of sufficient reason for the persecution, the manner of carrying it out by destroying property, injuring persons, and throwing things about, the impertinent answers given by the spirit, and its displaying its tricks to all and sundry in broad day-light, are an exact parallel to the troubles of Gilbert Campbell in the story of the "Devil of Glenluce." How far self-deception or human mischief entered into these occurrences is a problem for the investigator of ghosts. In the case of a similar Icelandic story, narrated in $175^{\circ}$ by the Sheriff Hans Wium, who was an eye-witness to the reality of the events, there was a suspicion that they were brought about by a young man who was said to have learned ventriloquism abroad. ${ }^{1}$ This might explain the conversations which the invisible one kept up with the sheriff and others, but can scarcely account for some of his other feats, such as throwing the door off its hinges into the room.

It is possible that such tales may be the historical descendants of the more impressive ghosts of antiquity. A figure like Glám in Grettis Saga is not after all far removed from the Bócan; their origin and behaviour are much the same, and a good many points of resemblance might be made out. In that case the later ones are very degenerate specimens; but there is something of mystery about Donald Bán's persecutor that makes him a rather superior member of his class.

1 This is the explanation given in Huld (Reykjavik, 1893) part 3, p. 25. Wium's letter about the IIjaltastad fiend is also printed in Jón Amason's collection, vol. i. pp. 309-31r. 